\title{
Ultrasonographic evaluation of the equine placenta
}

\author{
M. H. T. Troedsson \\ Department of Clinical and Population Sciences, College of Veterinary Medicine, University of Minnesota
}

\begin{abstract}
Summary
Placentitis is a common cause of equine abortions. In a majority of cases, the route of infection is believed to be ascending through the cervix, and an area of the chorion adjacent to the cervical star shows characteristic pathology in aborting mares. This area is depleted of chorionic villi, thickened, discolored, and covered by fibronecrotic exudate. Mares with placentitis due to a hematogenous infection show multifocal pathology of the chorionic surface of the placenta. Clinical signs include udder development, premature lactation, cervical softening, and vaginal discharge. Treatment is often unsuccessful once the mare has developed clinical signs. Ultrasonographic evaluation of the placenta in late gestational mares allows the clinician to detect preclinical signs of placentitis and premature separation, which then could be treated in its early stages.

Transabdominal ultrasonography: Focal areas of utero-placental thickening and partial separation of the allantochorion from the endometrium in the uterine body and horns, can be observed by this approach. The combined thickness of the uterus and the placenta (CTUP) should not be more than $12 \mathrm{~mm}$ at any site. In addition to evaluating the placenta, a biophysical profile of the fetus can be performed by a transabdominal approach. Transrectal ultrasonography: This approach provides an excellent image of the caudal portion of the allantochorion adjacent to the cervical star. Using transrectal ultrasonographic evaluation of the placenta, we have observed abnormal thickness and partial separation of the allantochorion from the endometrium in mares with clinical signs of placentitis. In advanced stages, the space between the uterus and the placenta is filled with hyperechoic fluid. Normal values of the CTUP in an area immediately cranially and ventrally of the cervix was determined to be: $<8 \mathrm{~mm}$ between day 271 and 300; $<10 \mathrm{~mm}$ between day 301 and 330; and <12 mm after day 330. Increased CTUP suggests placental failure and pending abortion.

Treatment of placentitis should be aimed toward elimination of the infectious agents, reduction of the inflammatory response, and reduction of the increased myometrial contractility in response to the ongoing inflammation. Broad spectrum antibiotics, anti-inflammatories (flunixin meglumine, $1.1 \mathrm{mg} / \mathrm{kg}$ BID; phenylbutazone, $4 \mathrm{mg} / \mathrm{kg} \mathrm{BID)}$ ) and tocolytics (Altrenogest, $0.088 \mathrm{mg} / \mathrm{kg} \mathrm{SID;Clenbuterol,} 0.8 \mu \mathrm{g} / \mathrm{kg}$ ), are recommended for treatment of placentitis. Pentoxyfylline $(7.5 \mathrm{mg} / \mathrm{kg}$ p.o. BID) has been suggested to increase oxygenation of the placenta through an increased deformability of red blood cells.
\end{abstract}

Keywords: equine, pregnancy, placentitis, ultrasonography

\section{Ultrasonographische Untersuchung der equinen Plazenta}

Eine häufige Ursache für Aborte bei der Stute ist eine Plazentitis. In den meisten Fällen wird eine aufsteigende Infektion über die Zervix vermutet, dabei weist der zervixnahe Chorionbereich charakteristische pathologische Befunde bei den abortierenden Stuten auf. Dieser Bereich zeigt eine Depletion der Chorionzotten, ist verdickt, missfarben und von einem fibrinös-nekrotischem Exudat bedeckt. Stuten mit einer hämatogen entstandenen Plazentitis weisen multifokale Veränderungen der Chorionoberfläche auf. Klinische Symptome sind Aufeutern, vorzeitige Laktation, eine Erschlaffung des weichen Geburtsweges und vaginaler Ausfluss. Nach dem Auftreten klinischer Symptome ist eine Therapie meist wenig erfolgversprechend. Mittels Ultraschall der Plazenta in der Spätträchtigkeit kann der Kliniker subklinische Anzeichen einer Plazentitis und einer vorzeitigen Ablösung feststellen, so dass bereits in diesem frühen Stadium eine Therapie eingeleitet werden kann. Transabdominaler Ultraschall: Mit dieser Vorgehensweise können herdförmige Verdickungen des Uterus und der Plazenta und ein partielle Ablösung des Allantochorions von dem Endometrium sowohl im Uteruskörper als auch in den Hörnern diagnostiziert werden. Die Dicke von Uterus und Plazenta zusammen (CTUP) sollte an keiner Stelle mehr als $12 \mathrm{~mm}$ betragen. Zusätzlich zur Bewertung der Plazenta kann der Fetus biophysisch mit dieser transabdominalen Untersuchung beurteilt werden.

Transrektaler Ultraschall: Diese Methode ergibt exzellente Bilder von dem kaudalen an die Zervix angrenzenden Anteil des Allantochorions. Mit Hilfe des transrektalen Ultraschalls haben wir bei Stuten mit klinischen Anzeichen einer Plazentitis eine abnorme Verbreiterung und partielle Ablösung des Allantochorions vom Endometriums beobachtet. In fortgeschrittenen Stadien ist der Spalt zwischen Uterus und Plazenta mit hyperechogener Flüssigkeit gefüllt. In den Bereichen kranial und ventral der Zervix wurden folgende Normalwerte für den CTUP bestimmt: $<8 \mathrm{~mm}$ zwischen dem 271. und dem 300. T ag, $<10 \mathrm{~mm}$ zwischen dem 301. und dem 330. T ag und $<12 \mathrm{~mm}$ nach dem 330 . T ag. Erhöhte CTUP-Werte sprechen für eine Ablösung der Plazenta und einen drohenden Abort. Die Therapie einer Plazentitis sollte die Elimination des infektiösen Agens, eine Reduktion der Entzündung und der wegen der Entzündung erhöhten Kontraktilität des Endometriums zum Zie haben. Breitspektrumantibiotika, Entzündungshemmer (Flunixin Meglumin, 1,1 mg/kg BID; Phenylbutazon, 4 mg/kg BID) und T okolytica (Altrenogest, 0,088 mg/kg SID; Clenbuterol, 0,8 $\mu \mathrm{g} / \mathrm{kg}$ ) werden zur Therapie einer Plazentitis empfohlen. Pentoxyfyllin (7,5 mg/kg p.o. BID) kann eingesetzt werden, um die Saverstoffversorgung der Plazenta durch eine erhöhte Verformbarkeit der Erythrozyten zu verbessern.

Schlüsselwörter: Pferd, Trächtigkeit, Plazentitis, Ultraschall

\section{Introduction}

Improved diagnostic techniques and advances in the understanding of equine reproductive physiology and pathology have resulted in increased pregnancy rates in mares. In contrast, the incidence of pregnancy loss has remained fairly constant at a rate of 10-15\% (Roberts, 1986). Early pregnancy loss have been reported to be $20 \%$ in fertile mares and greater than $70 \%$ in subfertile mares (Ball, 1993). Several causes have been identified, but the clinician is often left without effective treatments 
to prevent the pregnancy loss. Pregnancy losses during late gestation (> 5 months) represent an even greater problem for the equine breeding industry. Affected mares will not only fail to produce a foal, but will often have a lower conception rate during the next breeding season. Pregnancy losses during late gestation could be the result of fetal illness, placental dysfunction, or maternal illness. Monitoring of maternal health and preventive treatments of the pregnant mare against diseases that may cause abortion, have been performed for decades. However, monitoring of the equine fetus and the placenta during late gestation has only recently gained recognition. A thorough examination of the placenta post partum provides valuable information on disease processes or dysfunctions that could have affected the well being of an aborted fetus, or potentially cause illness in the neonatal foal. However, this examination does not aid the clinician in decisions that are aimed to prevent abortion or neonatal diseases of the foal.

Placentitis and twin pregnancy are the most common causes of placental failure and equine abortions (Acland, 1993; Giles et al., 1993). Twin pregnancies can be detected by the use of transrectal ultrasonography as early as 11-14 days of gestation, and can be managed successfully by the use of manual reduction, ultrasound guided aspiration of the embryonic vesicle, or fetal heart puncture and intracardial injection of $\mathrm{KCl}$ as previously described (Pascoe et al., 1987; Rantanen and Kencaid, 1989). In the majority of placentitis cases, the route of infection is believed to be ascending through the cervix, and an area of the chorion adjacent to the cervical star shows characteristic pathology in aborting mares. This area is depleted of chorionic villi, thickened, discolored, and covered by fibronecrotic exudate. Mares with placentitis due to a hematogenous infection show multifocal pathology of the chorionic surface of the placenta. Clinical signs include udder development, premature lactation, cervical softening, and vaginal discharge. Treatment is often unsuccessful once the mare has developed clinical signs. Ultrasonographic evaluation of the placenta in late gestational mares allows the clinician to detect pre-clinical signs of placentitis and premature separation, which then could be treated in its early stages.

\section{Ultrasonographic evaluation of the placenta}

The chorionic part of the allantochorion is attached to the endometrium through microcotyledons, which integrate the endometrium throughout the uterus with exception of a small area at the internal os of the cervix, the so-called cervical star. The allantochorion supports the fetus in utero. It provides respiratory and nutrient exchange between the mare and the fetus, and it is an endocrine active organ with hormone synthesis and metabolism of importance for maintenance and normal development of the fetus. Areas of utero-placental thickness and partial separation of the allantochorion from the endometrium can be visualized in the uterine body and horns, using transabdominal ultrasonography (Figure 1). However, the caudal portion of the allantochorion cannot be imaged by this approach, resulting in difficulties to diagnose early stages of ascending placentitis. Transrectal ultrasonography of the caudal allantochorion in late gestational mares provides an excellent image of the placenta close to the cervical star (Figure 2).

Transabdominal ultrasonography: Ultrasonographic examinations of the placenta in mares that are considered to be at risk for abortion during late gestation are routinely performed by a transabdominal approach, using a 5 or a $7.5 \mathrm{MHz}$

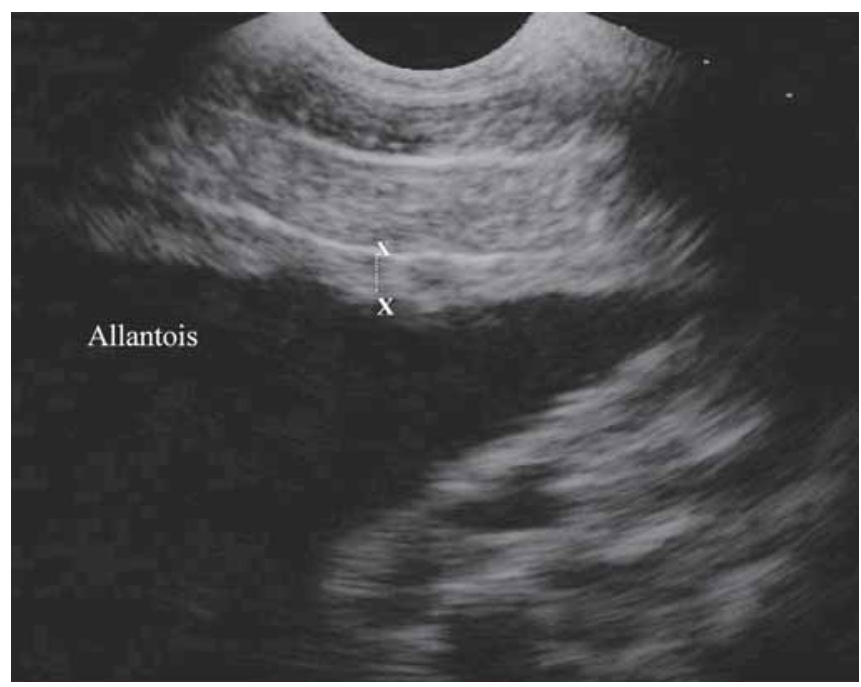

Fig. 1: Transabdominal ultrasound image of the uteroplacental unit in a normal late gestational mare. The $X$ marks the thickness of the uteroplacental unit (CTUP)

Transabdominales Ultraschallbild der uteroplazentalen Einheit bei einer Stute in einer normalen späten Trächtigkeit. Die Kreuze markieren die Breite der uteroplazentalen Einheit (CTUP).

transducer (Adams-Brendemuehl and Pipers, 1987; Vaala and Sertich, 1994; Reef et al., 1996; Figure 1). Normal values for the combined thickness of the uterus and the placenta (CTUP) have been established (Adams-Brendemuehl and Pipers, 1987; Reef et al., 1995). Using this technique, it was suggested that mares with normal pregnancies should have a minimal CTUP of $7.1 \pm 1.6 \mathrm{~mm}$, and a maximum CTUP of $11.5 \pm 2.4 \mathrm{~mm}$. In a subsequent study, it was observed that mares with an increased CTUP often delivered abnormal foals (Reef et al., 1996). A CTUP of $>17.5 \mathrm{~mm}$ has been suggested to be consistent with placentitis (Schott, 1993). Renaudin et al. (1997) found a significant difference in the CTUP between pregnancy months in mares with normal pregnancies. However, the CTUP did not increase consistently, and the reliability of measuring CTUP by a transabdominal approach was questioned. Nevertheless, placental thickening and partial separation of the allantochorion from the endometrium may be observed by the use of transabdominal ultrasonography in mares with placentitis originating from hematogenous infection (Figure 3). In addition, a pocket of hyperechoic fluid can be seen at the base of the lowest area of the uterus in mares with the Nocardia form of placentitis. One advantage in using a transabdominal approach to monitor the placenta is that a biophysical profile of the fetus can be performed at the same time (Reef et al., 1996).

Mares grazing endophyte-infected fescue often experience premature separation of the allantochorion, increased allantochorion weight and thickness, and retained placenta. A significant increase in uteroplacental thickness and premature 
separation of the allantochorion has been demonstrated on transabdominal ultrasonographic examination of endophyteinfected mares. However, the thickness was not observed until an average of 8 hours before the onset of labor (Brendemuehl et al., 1996).

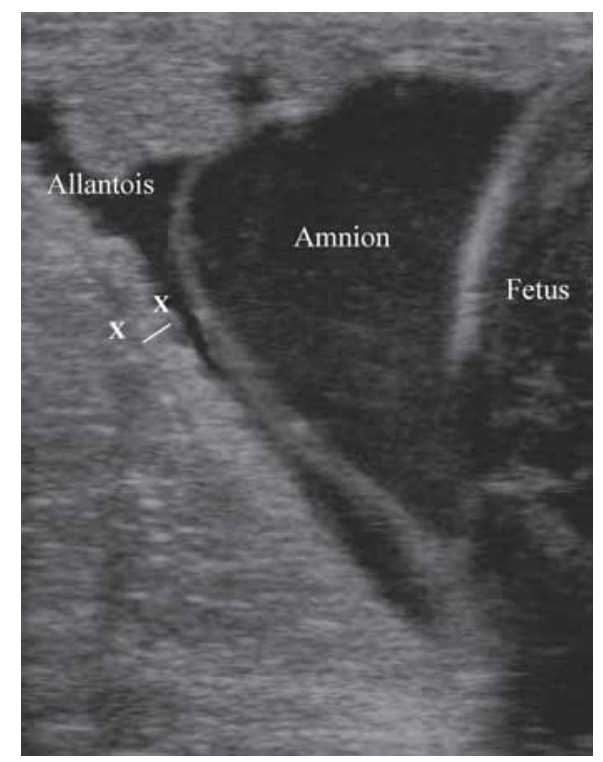

Fig. 2: Transrectal ultrasonographic image of a late gestational mare. The combined thickness of the uterus and the placenta (CTUP; $x-x$ ) is measured approximately $5 \mathrm{~cm}$ cranial of the cervix in the ventral aspect of the uterine body between the allantoic fluid and the middle branch of the uterine artery.

Transrektales Ultraschallbild einer Stute in der späten Trächtigkeit. Die gemeinsame Breite von Uterus und Plazenta (CTUP; $x-x$ ) wird etwa 5 $\mathrm{cm}$ kranial der Zervix im ventralen Bereich des Uteruskörpers zwischen Allantoisflüssigkeit und dem mittleren Ast der Arteria uterina gemessen.

Transrectal ultrasonography: This approach provides excellent image of the caudal portion of the allantochorion adjacent to the cervical star. A technique to measure the CTUP in this area has been established (Renaudin, 1997). A $5 \mathrm{MHz}$ linear transducer was positioned 1-2 inches cranial of the cervical-

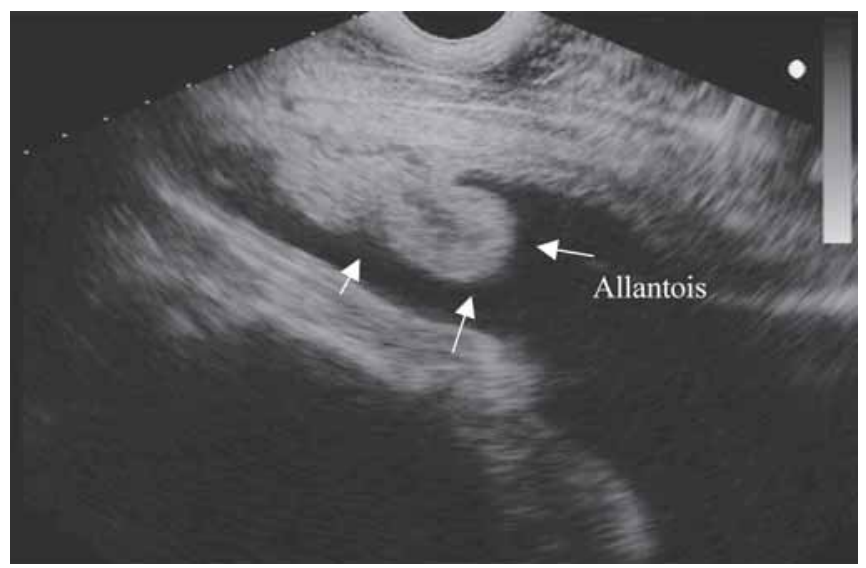

Fig. 3: Transabdominal ultrasonographic image of a late gestational mare. The arrows point to an area with folding and partial separation of the allantochorion.

Transabdominales Ultraschallbild einer Stute in der späten Phase der Trächtigkeit. Die Pfeile markieren ein Gebiet mit Einfaltungen und partieller Ablösung des Allantochorions. placental junction, and then moved laterally until the middle branch of the uterine artery was visible at the ventral aspect of the uterine body. The CTUP should be measured between the middle branch of the uterine artery and the allantoic fluid (Figure 2). The examiner has to ensure that the amniotic membrane is not adjacent to the allantochorion, since this may result in false increased CTUP. The CTUP should be measured in the ventral part of the uterine body. The CTUP in the dorsal part of the uterus is often edematous in normal pregnant mares during the last month of gestation. A CTUP $>8 \mathrm{~mm}$ between day 271 and $300,>10 \mathrm{~mm}$ between day 301 and 330 , and $>12 \mathrm{~mm}$ after day 330 suggests placental failure and pending abortion (Troedsson et al., 1997).

Using transrectal ultrasonography, an abnormal thickness and partial separation of the allantochorion from the endometrium has been observed in mares with clinical signs of ascending placentitis. In advanced stages, the space between the uterus and the placenta is filled with hyperechoic fluid. In a field study on Thoroughbred mares at commercial stud farms in central Kentucky, all mares with normal thickness of the placenta carried their foals to term, and all mares that aborted due to placentitis, had a marked increase of the CTUP or placental detachment.

\section{Management of mares with placentitis}

Treatment of mares with ultrasonographic signs of placentitis should be aimed toward elimination of the infectious agents, reduction of the inflammatory response, and reduction of the increased myometrial contractility response to the ongoing inflammation. No controlled studies have been reported on the efficacy of treatments for mares with placentitis. The following recommendations are based on clinical experience and extrapolation from other species. Broad spectrum antibiotics, anti-inflammatories such as flunixin meglumine (1.1 mg/kg BID), phenylbutazone (4 mg/kg BID), and tocolytics such as Altrenogest $(0.088 \mathrm{mg} / \mathrm{kg} \mathrm{SID)}$, and clenbuterol $(0.8 \mu \mathrm{g} / \mathrm{kg}$ BID) have been recommended (Troedsson et al., 1997). Pentoxyfylline (7.5 mg/kg p.o. BID) has been suggested to increase oxygenation of the placenta through an increased deformability of red blood cells.

The average $( \pm$ SEM) birth weight of foals from mares who had been treated for placentitis during late gestation was $48 \pm 5.3$ $\mathrm{kg}(\mathrm{n}=5)$ compared to $55.5 \pm 1 \mathrm{~kg}(\mathrm{n}=152)$ in mares with normal pregnancies, in a retrospective study from a commercial stud farm (Troedsson, unpublished data). Great variations were observed among foals from treated mares $(31.8 \mathrm{~kg}-61.8 \mathrm{~kg})$, and there is no current diagnostic method to predict how the compromised uterine environment in a mare with placentitis will affect the development of her fetus in individual cases.

While transrectal and transabdominal ultrasonographic examination of the placenta is useful to detect early signs of some placental pathology, it is important to keep in mind that placental changes resulting in periparturian problems can be subtle and may not readily be detected on ultrasonographic examination. For example, a correlation between both endometrial fibrosis and angiosis, and poor chorionic villous deve- 
lopment has been reported (Bracher et al., 1996; Schoon et al., 1999). These changes can of course not be evaluated by the use of ultrasonography, but would require other techniques.

\section{Literature}

Acland, H. M. (1993): Abortion in mares. In: Equine Reproduction, eds: A.O. McKinnon \& J.L. Voss. Lea \& Febiger, Philadelphia, PA, 554-562.

Adams-Brendemuehl, C. and Pipers F. S. (1987): Antepartum evaluations of the equine fetus. J. Reprod. Fert. (Suppl.), 35, 565-573.

Ball B. A. (1993): Embryonic death in mares. In: Equine Reproduction, eds: A.O. McKinnon \& J.L. Voss. Lea \& Febiger, Philadelphia, PA, 517-531.

Boosinger, T. R., Brendemuehl, J. P., Schumacher, J., Bransby, D. I., Kee, D. and Shelby, R. A. (1995): Effects of short-term exposure to and removal from the fescue endophyte Acremonium coenophialum at 300 days of gestation on pregnant mares and foal viability, Biol. Reprod. Monograph Series 1: Equine Reprod. VI, 61-67.

Bracher, V., Mathias, S. and Allen, W. R. (1996): Influence of chorionic degenerative endometritis (endometrosis) on placental development in the mare. Equine Vet. J. 28, 180-188.

Giles, R. C., Donahue, J. M., Hong, C. B., Tuttle, P. A., Petrites-Murphy, M. B., Poonacha, K. B., Roberts, A. W., Tramontin, R. R., Smith, B. and Swerczek, T. W. (1993): Causes of abortion, stillbirth, and perinatal death in horses: 3527 cases (1986-1991). JAVMA, 203, 1170 1175.

Pascoe, D. R., Pascoe, R. R., Hughes, J.P., Stabenfeldt, G.H. and Kindahl, H. (1987): Comparison of two techniques and three hormone therapies for management of twin conceptuses by manual embryonic reduction. J. Reprod. Fert. (Suppl), 35, 701-702.

Rantanen, N. W. and Kencaid, B. (1989): Ultrasound guided fetal cardiac puncture: A method of twin reduction in the mare. Proc. AAEP, 35, 173-179.

Reef, V. B., Vaala, W. E., Worth, L. T. Sertich, P. L., Spencer, P. A. and Hammomd, B. (1995): Ultrasonographic evaluation of the fetus and intrauterine environment in healthy mares during late gestation. Vet. Rad. and Ultrasound, 36, 533-541.

Reef, V. B., Vaala, W. E., Worth, L. T., Sertich, P. L. and Spencer, P. A. (1996): Ultrasonographic assessment of fetal well being during late gestation: development of an equine biophysical profile. Equine Vet. J., 28, 200-208.

Renaudin, C., Troedsson, M. H. T., Gillis, C, King, V. L. and Bodena, A. (1997): Ultrasonographic evaluation of the equine placenta by transrectal and transabdominal approach in pregnant mares. Theriogenology, 47, 559-573.

Roberts, S. J. (1986): In: Veterinary obstetrics and genital diseases (Theriogenology), 3rd ed., North Pomfret, Vt, S.J. Roberts, pp 38-50; 162.

Schoon D., Schoon H.-A., and Klug E. (1999): Angioses in the equine endometrium: pathogenesis and clinical correlations. Pferdeheilkunde, 15, 541-546.

Schott II, H. C. (1993): Assessment of fetal well-being. In: McKinnon A.O. \& Voss J.L.. Equine Reproduction, Philadelphia: Lea \& Febiger, 964-975.

Troedsson, M. H. T., Renaudin, C. D., Zent, W. W., Steiner, J. V. (1997): Transrectal ultrasonography of the placenta in normal mares and in mares with pending abortion: A field study. Proc. Am. Assoc. Equine Pract., 43, 256-258.

Vaala, W. E. and Sertich, P. L. (1994): Management strategies for mares at risk for periparturient complications. Vet. Clin. North Am.: Equine Pract., 10, 237-265.

\section{Prof. Dr. M. H. T. Troedsson}

Department of Clinical and Population Sciences

College of Veterinary Medicine

495 AnSci/VetMed Building

1988 Fitch Avenue

St. Paul, MN 55108, USA

Fax.: 001-612-6252743

e-mail: troed001@maroon.tc.umn.edu 